\title{
A COMPARATIVE STUDY OF PRECISE POINT POSITIONING (PPP) ACCURACY USING ONLINE SERVICES
}

\author{
Marcin Malinowski, Janusz Kwiecień \\ UTP University of Science and Technology in Bydgoszcz, \\ Faculty of Civil and Environmental Engineering and Architecture, Poland
}

\begin{abstract}
Precise Point Positioning (PPP) is a technique used to determine the position of receiver antenna without communication with the reference station. It may be an alternative solution to differential measurements, where maintaining a connection with a single RTK station or a regional network of reference stations RTN is necessary. This situation is especially common in areas with poorly developed infrastructure of ground stations. A lot of research conducted so far on the use of the PPP technique has been concerned about the development of entire day observation sessions. However, this paper presents the results of a comparative analysis of accuracy of absolute determination of position from observations which last between 1 to 7 hours with the use of four permanent services which execute calculations with PPP technique such as: Automatic Precise Positioning Service (APPS), Canadian Spatial Reference System Precise Point Positioning (CSRS-PPP), GNSS Analysis and Positioning Software (GAPS) and magicPPP - Precise Point Positioning Solution (magicGNSS). On the basis of acquired results of measurements, it can be concluded that at least two-hour long measurements allow acquiring an absolute position with an accuracy of 2-4 cm. An evaluation of the impact on the accuracy of simultaneous positioning of three points test network on the change of the horizontal distance and the relative height difference between measured triangle vertices was also conducted. Distances and relative height differences between points of the triangular test network measured with a laser station Leica TDRA6000 were adopted as references. The analyses of results show that at least two hours long measurement sessions can be used to determine the horizontal distance or the difference in height with an accuracy of 1-2 cm. Rapid products employed in calculations conducted with PPP technique reached the accuracy of determining coordinates on a close level as in elaborations which employ Final products.
\end{abstract}

Keywords: Precise Point Positioning, PPP, GPS, APPS, CSRS-PPP, GAPS, magicGNSS 


\section{Introduction}

Precise Point Positioning (PPP) is a technique of precise satellite positioning which has been developed for about 15 years (Zumberge et al.,1997; Kouba et al., 2001; Gao et al., 2004; Gao 2011; Guo, 2015; Leandro et al., 2009; Cai et al., 2007). The main advantage of PPP method is its ability to determine positions with a high accuracy using only one dual frequency GNSS receiver without communication with a regional reference network or station. Such technology reduces the need to maintain a costly regional network of reference stations and allows measurements to be conducted in areas with poorly developed ground infrastructure. Acquiring high accuracy of positioning is possible due to employment of precise products made available by International GNSS Service (IGS), such as parameters of: rotation of the earth, clocks of satellites with an interval of 30 seconds and orbits of satellites made accessible at intervals of 15 minutes. The accuracy of disclosed ephemeris of satellites of GPS system is around $2.5 \mathrm{~cm}$ and for GLONASS system, it is around 5 $\mathrm{cm}$. Information about selected IGS products is reported in Table 1. The quality of the aforementioned products allows IGS to perform basic tasks such as, realization of a global precise frame of reference, research of rotation of the earth, movement of poles and tidal phenomena, research of change of the sea and ocean level and research of the atmosphere (ionosphere and troposphere).

Tab. 1. IGS products employed in PPP

\begin{tabular}{|c|c|c|c|c|c|}
\hline & Type & Accuracy & Delay & $\begin{array}{c}\text { Frequency of } \\
\text { update }\end{array}$ & Interval \\
\hline \multicolumn{6}{|c|}{ Ephemeris of Satellites } \\
\hline \multicolumn{2}{|r|}{ Rapid } & $\sim 2,5 \mathrm{~cm}$ & $17-41 \mathrm{~h}$ & $\begin{array}{c}\text { Daily on 17:00 } \\
\text { UTC }\end{array}$ & 15 minutes \\
\hline \multicolumn{2}{|r|}{ Final } & $\sim 2,5 \mathrm{~cm}$ & 12-18 days & Every Thursday & 15 minutes \\
\hline \multicolumn{6}{|c|}{ Clocks of satellites } \\
\hline \multirow{2}{*}{\multicolumn{2}{|c|}{ Rapid }} & $\sim 75$ ps RMS & \multirow{2}{*}{$17-41 \mathrm{~h}$} & \multirow{2}{*}{$\begin{array}{c}\text { Daily on } 17: 00 \\
\text { UTC }\end{array}$} & \multirow{2}{*}{5 minutes } \\
\hline & & $\sim 25$ ps SDev & & & \\
\hline \multirow{2}{*}{\multicolumn{2}{|c|}{ Final }} & $\sim 75$ ps RMS & \multirow{2}{*}{$12-18$ days } & \multirow{2}{*}{ Every Thursday } & \multirow{2}{*}{30 seconds } \\
\hline & & $\sim 25$ ps SDev & & & \\
\hline \multicolumn{6}{|c|}{ Parameters of Rotation of Earth } \\
\hline \multirow{3}{*}{ Rapid } & $\begin{array}{l}\text { Movement of } \\
\text { pole }\end{array}$ & $\sim 40 \mu$ as & \multirow{3}{*}{$17-41 \mathrm{~h}$} & \multirow{3}{*}{$\begin{array}{c}\text { Daily on 17:00 } \\
\text { UTC }\end{array}$} & \multirow{3}{*}{$\begin{array}{c}\text { Daily on } 12: 00 \\
\text { UTC }\end{array}$} \\
\hline & $\begin{array}{l}\text { Change of } \\
\text { parameters of } \\
\text { the movement } \\
\text { of pole }\end{array}$ & 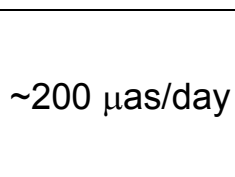 & & & \\
\hline & Length of day & $\sim 10 \mu \mathrm{a}$ & & & \\
\hline \multirow{3}{*}{ Final } & $\begin{array}{l}\text { Movement of } \\
\text { pole }\end{array}$ & $\sim 30 \mu$ as & \multirow{3}{*}{$11-17$ days } & \multirow{3}{*}{ Every Thursday } & \multirow{3}{*}{$\begin{array}{c}\text { Daily on } 12: 00 \\
\text { UTC }\end{array}$} \\
\hline & $\begin{array}{l}\text { Change of } \\
\text { parameters of } \\
\text { the movement } \\
\text { of pole }\end{array}$ & 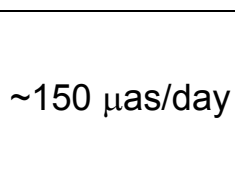 & & & \\
\hline & Length of day & $\sim 10 \mu \mathrm{a}$ & & & \\
\hline
\end{tabular}

RMS - Root Mean Square; SDev - Standard Deviation; $100 \mu \mathrm{s}=3,1 \mathrm{~mm}$ equatorial rotation; $10 \mu \mathrm{s}=$ $4,6 \mathrm{~mm}$ of equatorial rotation. (Source: https://igscb.jpl.nasa.gov/components/prods.html, 15.01.2016) 
Realization of tasks which is the goal of IGS would be impossible without around 350 permanent tracking stations, global and regional data centers, and numerous analysis centers. In the case of measurements conducted with PPP technique, even if a connection with a regional reference network or station is not required, the access to precise products disclosed by IGS and created on the basis of a global network of permanent tracking stations is essential. In PPP technique, a number of additional data and corrections are taken into consideration (Tab. 2) in order to reach a high accuracy of positioning (Choy, 2011; Rizos et al. 2012). Precise orbits and corrections to clocks of satellites are essential. While conducting measurements in post-processing mode, ionospheric and tropospheric corrections are also included as well as tide of oceans and earth's crust, the location of the phase center of the satellite or receiver antenna and effects of the relativity theory.

Tab. 2. List of corrections for PPP and DGNSS. (Rizos et al. 2012)

\begin{tabular}{|c|l|c|c|}
\hline \multicolumn{2}{|c|}{ Type of correction } & PPP & $\begin{array}{c}\text { DGNSS } \\
\text { (L1+L2) }\end{array}$ \\
\hline \multirow{4}{*}{$\begin{array}{c}\text { Errors of } \\
\text { satellite }\end{array}$} & Precise satellite clock corrections & + & - \\
\cline { 2 - 4 } & Precise satellite orbits corrections & + & - \\
\cline { 2 - 4 } & Satellite antenna phase centre offset and its & + & + \\
\cline { 2 - 4 } & Group delay differential & + & - \\
\cline { 2 - 4 } & Relativity terms & + & - \\
\cline { 2 - 4 } & Satellite antenna phase wind up error & + & - \\
\hline \multirow{2}{*}{$\begin{array}{c}\text { Errors of } \\
\text { receiver }\end{array}$} & $\begin{array}{l}\text { Receiver antenna phase centre offset and its } \\
\text { variations }\end{array}$ & + & + \\
\cline { 2 - 4 } & Receiver antenna phase wind up error & + & - \\
\hline \multirow{2}{*}{$\begin{array}{c}\text { Errors of } \\
\text { models of } \\
\text { geophysical } \\
\text { phenomena }\end{array}$} & Crust tides & + & - \\
\cline { 2 - 4 } & Ocean tides & + & - \\
\cline { 2 - 4 } $\begin{array}{c}\text { Errors of } \\
\text { atmospheric } \\
\text { models }\end{array}$ & Plate tectonic motion & + & + \\
\cline { 2 - 4 } & Troposphere delay & + & + \\
\hline
\end{tabular}

Calculation methodology of precise absolute positioning is well described in literature (Cai et al., 2007; Choy, 2011). It is based on code and phase observations at both frequencies. Equations of code and phase observations at L1 frequency are recorded in the following manner (Cai et al., 2007):

$$
\begin{gathered}
P_{1, i}^{k}=\rho_{i}^{k}+c\left(\Delta t_{i}-\Delta t^{k}\right)+\delta O^{k}+\delta T_{i}^{k}+\delta I_{i}^{k}+\varepsilon \\
\Phi_{1, i}^{k}=\rho_{i}^{k}+c\left(\Delta t_{i}-\Delta t^{k}\right)+\delta O^{k}+\delta T_{i}^{k}-\delta I_{i}^{k}+\lambda_{L 1} N_{L 1, i}^{k}+\varepsilon
\end{gathered}
$$

where:

$P_{1, i}^{k} \quad$ - pseudorange from $\mathrm{k}$ satellite to the receiver and at L1 frequency [m],

$\Phi_{1, i}^{k} \quad$ - phase observation of the receiver and from $\mathrm{k}$ satellite at L1 frequency [m],

$\rho_{i}^{k} \quad$ - geometric distance between $\mathrm{k}$ satellite and i receiver [m],

$\Delta t_{i}, \Delta t^{k}$ - errors of clocks of i receiver and $\mathrm{k}$ satellite [s],

$\delta O^{k}-$ error of the orbit for k satellite [m], 


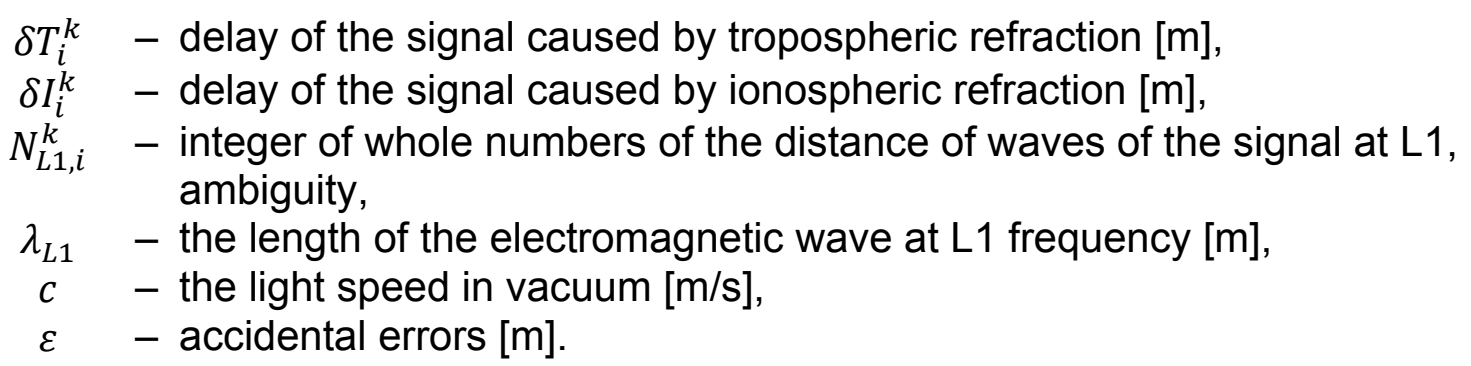

Values determined in the process of calculations are coordinates of the receiver, error of the receiver's clock, tropospheric delay and ambiguity. The error of ephemeris and the error of the satellite's clock is reduced by using precise products of IGS (Tab. 1). The error of ionospheric delay is most commonly eliminated by employing dual frequency receiver (Cai et al., 2007). Hence, elimination of ionospheric refraction can be achieved by use of ionosphere-free type line combination for code and phase observations. The tropospheric delay does not rely on the frequency of GNSS signal so it is treated as unknown (Gao, 2011). The ambiguity of the phase (the number of full phase cycles of GNSS signal) is very difficult to fix in absolute measurements. Determination of the value of the unknown requires long term observations (Gao, 2011, Geng et al., 2010). However, most often it is a real number which yields a float type solution. Similarly PPP solution implemented in Bernese yields a float type solution where ambiguity are real numbers (Stępniak et al., 2012).

In developing satellite observations using PPP technique, one can employ specialist software such as the Bernese GPS Software, EZSurv and a package of open-source software RTKLib. The alternative solution is the use of online services which conduct calculations using PPP. A list of such sites is shown in Tab. 3.

CSRS-PPP service (Canadian Spatial Reference System) develops data in static and kinematic modes using precise corrections to orbits and clocks of satellites made accessible by IGS. Calculations may conducted on the basis of code and phase observations at single or dual frequencies. The user may choose NAD83 or ITFR2008 frame of reference where coordinates can be determined. There is also a possibility of sending OTL file (Ocean Tidal Loading) with data on ocean tides. Observations from constellations GPS and GLONASS can be used for the development of data. The use of the aforementioned services is associated with a compulsory registration.

APPS (Automatic Precise Positioning Service) and GAPS (GNSS Analysis and Positioning Software) services process data in static and kinematic mode during calculations. GAPS requires registration but APPS does not. In the process of registration for APPS, it is possible to change the option of processing observation by increasing the limit of sent file from $5 \mathrm{MB}$ to $10 \mathrm{MB}$. GAPS uses Final, Rapid and Ultra-rapid products for corrections of orbits and clocks of satellites made accessible by IGS and Natural Resources Canada (NRCan). APPS uses Final, Rapid and Ultrarapid type products of JPL (Jet Propulsion Laboratory) for corrections of orbits and clocks of satellites. People who use GAPS service may send a file with data on tides of the crust and oceans and a file with parameters of antenna's calibration. APPS service does not take into account in calculations parameters of phase center of antenna. Users of APPS may use observations only from the constellation of GPS in order to develop data, whereas in the case of GAPS from constellations of GPS, Galileo and BeiDou. 
The service of magicGNSS operated by the company GMV Aerospace and Defense is made available in two forms through an interactive web interface and through e-mail. The first method of communication requires registration. During calculations, it is possible to process data collected in static and kinematic mode at two frequencies using Final and Rapid products for corrections of orbits and clocks of satellites made accessible by IGS and GMV. In order to develop data, one may choose observations from constellations GPS, GLONASS, Galileo, BeiDou and QZSS. The outcome of the development is a report in the form of analysis enriched by graphic representations. Coordinates of the calculated position are determined in two frames of reference ITRF2008 and ETRS89. The service does not take into account in calculations parameters of the phase center of antenna.

\section{Research methodology}

The scope of this field research covers the evaluation of accuracy of static determining positions of vertex of triangular test network with use of various PPP services available on the Internet. In order to gather data, four important and constantly used services for developing GNSS observations with use of PPP technique i.e. APPS, CSRS-PP, GAPS, magicGNSS (Tab. 3), were employed.

Tab. 3. Online services for calculations using PPP

\begin{tabular}{|c|c|}
\hline Name of service & Service provider \\
\hline Automatic Precise Positioning Service (APPS) & NASA - Jet Propulsion Laboratory (JPL) \\
\hline $\begin{array}{c}\text { Canadian Spatial Reference System Precise Point } \\
\text { Positioning (CSRS-PPP) }\end{array}$ & Natural Resources Canada (NRCan) \\
\hline $\begin{array}{c}\text { GNSS Analysis and Positioning } \\
\text { Software (GAPS) }\end{array}$ & University of New Brunswick (UNB) \\
\hline $\begin{array}{c}\text { magicPPP - Precise Point Positioning Solution } \\
\text { (magicGNSS) }\end{array}$ & GMV Aerospace and Defence S.A.U. (GMV) \\
\hline
\end{tabular}

As shown in Figure 1 below three points of test network were established in the vicinity of the building within the territory of University of Science and Technology (UTP) taking into account good conditions for visibility of satellites over the horizon. The stability each point of the test network was ensured with massive and deep foundation situated below the ground freezing depth. On top of the pole a metal cube with a central hole of $5 / 8$ inches for attaching measurement instruments with the use of a tripod was anchored. Scheme of localization of points of test network was presented in Figure 2.

In order to conduct measurements, three advanced GR-5 receivers of Topcon company were used. Two of them had an activated operation of GPS and GLONASS constellations and the third had just GPS. GR-5 receiver is one of first receivers of RTK class which joins together satellite measurements from GPS, GLONASS and Galileo systems. Field measurements were organized in a form of 5 measurement sessions. Each measurement session was conducted on a different day. 

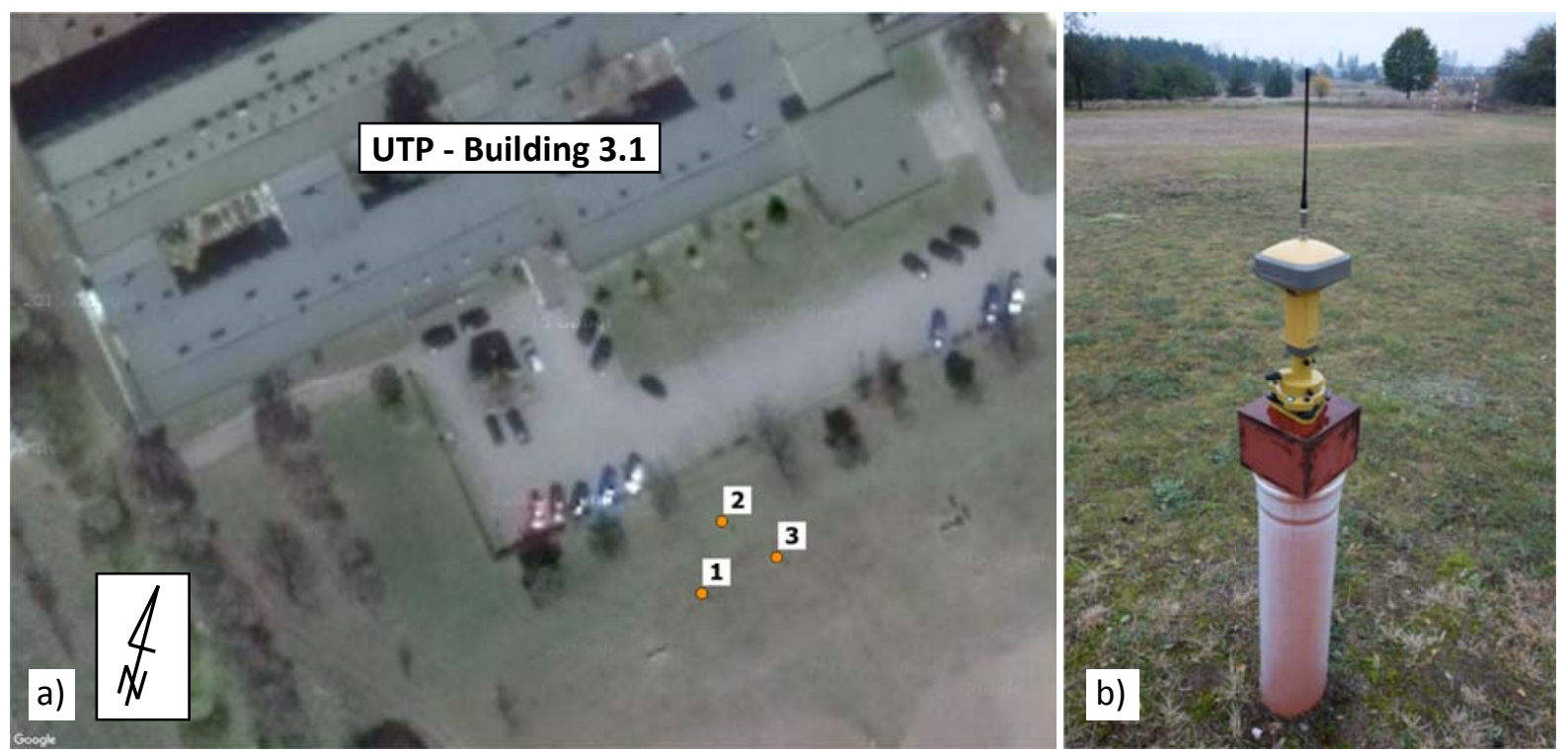

Fig. 1. Localization of: a) three points of geodesy test network in the vicinity of UTP Building 3.1. (Source: Google Maps); b) pole for attaching measurement instruments

The duration of a measurement session varies and was: 1:06h, 2:03h, 5:06h, 6:13h and 7:02h. Observations as static measurements were registered during measurement sessions in the internal memory of receivers. The process of data development began from conversion of files of measurement sessions from the file format of Topcon (.jps) to the universal format of data exchange RINEX 2.11. Service providers of web portals which make on-line calculations available has put a limit on the size of sent observation files. Such a situation demands conducting a filtration of data through dilution to 5,10 and 30 seconds long intervals. Observation files were prepared in one common form of recording. The files contained only standalone GPS observations. Parameters used during calculations by particular PPP services are reported in Table 4.

Tab. 4. Parameters adopted by online services for calculations with PPP

\begin{tabular}{|c|c|c|c|c|}
\hline Parameter & APPS & CSRS-PPP & GAPS & magicGNSS \\
\hline Version & v5 & 1.0505211 & v6.0.0 & $?$ \\
\hline Mode of calculation & static & static & static & static \\
\hline Constellation & GPS & GPS, GLO & GPS & $\begin{array}{c}\text { GPS, GLO, } \\
\text { GPS+GLO }\end{array}$ \\
\hline Frequency & L1,L2 & L1,L2 & L1,L2 & L1,L2 \\
\hline Type of observation & code and phase & code and phase & code and phase & code and phase \\
\hline Antenna model & $\begin{array}{c}\text { not taken into } \\
\text { account }\end{array}$ & $\begin{array}{c}\text { taken into } \\
\text { account }\end{array}$ & $\begin{array}{c}\text { not taken into } \\
\text { account }\end{array}$ & $\begin{array}{c}\text { not taken into } \\
\text { account }\end{array}$ \\
\hline Frame of reference & ITRF2008 & ITRF2008 & ITRF2008 & $\begin{array}{c}\text { ITRF2008, } \\
\text { ETRF89 }\end{array}$ \\
\hline $\begin{array}{c}\text { Orbits and clocks of } \\
\text { satellites }\end{array}$ & JPL Final & IGS Final & $\begin{array}{c}\text { IGS Rapid, } \\
\text { IGS Final }\end{array}$ & $\begin{array}{c}\text { GMV Rapid, } \\
\text { IGS Rapid, IGS } \\
\text { Final }\end{array}$ \\
\hline $\begin{array}{c}\text { Tides of oceans } \\
\text { Tides of crust }\end{array}$ & yes & no & yes & yes \\
\hline $\begin{array}{c}\text { Angle of the cut-off } \\
\text { of horizon }\end{array}$ & $7,5^{\circ}$ & $10^{\circ}$ & yes & yes \\
\hline
\end{tabular}


The next step of development was conversion of coordinates of the observed point from ITRF2008 to ETRF89, and then to coordinate system 2000 in zone 6 (Rogowski et al., 2004). It was also decided to take into account on a standalone basis, the model of phase center of antenna in case the PPP service provider did not use it in Final results of the development.

a)

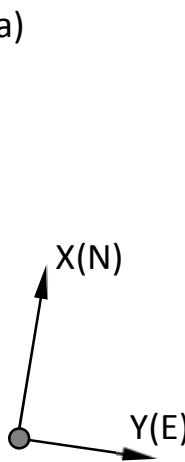

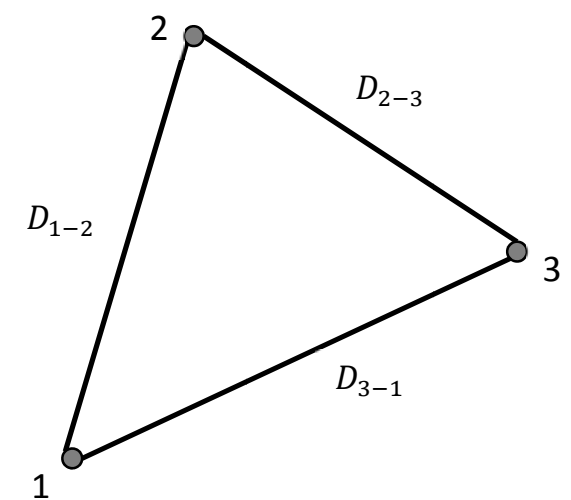

b)

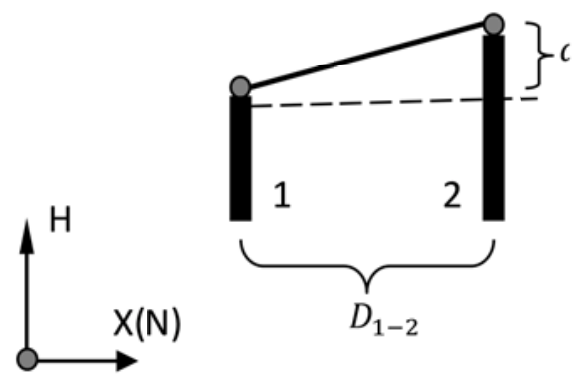

Fig. 2. Scheme of localization of points of geodesy test network on: a) horizontal plane,

b) schematic cross-section between points 1 and 2

For each point of test network, calculations were made using solely GPS observations and taking into account Rapid and Final products. GLONASS system was excluded because of lack of active service of that constellation in one of employed receivers. Acquired coordinates were compared with reference coordinates (Tab. 5). Because of the lack of daily measurement sessions in order to conduct an evaluation of accuracy of position of a single point of test network a postprocessing of observations was used through POZGEO service provided by the operator of ASG-EUPOS system. Calculations in POZGEO for sent observation files were gathered taking into account 6 close reference stations and calculated vectors to meet specific accuracy criteria. On the same basis, a alignment calculation was made to show coordinates of the observed point in ETRF2000 frame of reference. Additionally, coordinates were converted to 1965, 1992 and 2000 frames of references. Navigation orbits IGS-Rapid or IGS-Final are taken into account based on the date of sending the observation file for calculation. A model of phase center of antenna may be employed in calculations if its name appears after the site of the service provider in the catalogue of defined antenna models. Since July 14, 2014, when the amended bill introducing calculation fees came into force, the access to statistic services POZGEO and POZGEO D was closed down. When using POZGEO services for calculations, the following mean errors of determining position and the height for the longest session were acquired: $m_{p}=0.006 \mathrm{~m} ; m_{h}=0.003 \mathrm{~m}$, and for the shortest session respectively: $\mathrm{m}_{\mathrm{p}}=0.009 \mathrm{~m} ; \mathrm{m}_{\mathrm{h}}=0.006 \mathrm{~m}$. Additionally, mean values of deviations of components of the position from reference values, their standard deviations and maximum deviations were subjected to analysis.

Also an second experiment was conducted to determine the accuracy of horizontal distance and the relative height between points of test network. Measurements of horizontal distance and relative height between points of test network made with laser station LEICA TDRA6000 were adopted as values of reference (Tab. 6). Mean values of deviations of components of the position from reference values, their standard deviations and maximum deviations were subjected to analysis. 
Tab. 5. Reference values of coordinates of position on the points of test network calculated by POZGEO in Polish National Coordinate System 2000 zone 6

\begin{tabular}{|l|c|c|c|c|}
\hline $\begin{array}{c}\text { Number of } \\
\text { session }\end{array}$ & Time [h] & X Easting [m] & Y Northing [m] & H Height [m] \\
\hline \multicolumn{5}{|c|}{ Point 1 } \\
\hline Session 1 & $1: 09$ & 5889993.397 & 6508631.163 & 80.394 \\
Session 2 & $2: 03$ & 5889993.399 & 6508631.158 & 80.411 \\
Session 3 & $5: 06$ & 5889993.407 & 6508631.169 & 80.402 \\
Session 4 & $6: 13$ & 5889993.400 & 6508631.159 & 80.413 \\
Session 5 & $7: 02$ & 5889993.409 & 6508631.149 & 80.405 \\
\hline \multicolumn{5}{|c|}{ Point 2 } \\
\hline Session 1 & $1: 09$ & 5890003.106 & 6508633.936 & 80.941 \\
Session 2 & $2: 03$ & 5890003.123 & 6508633.940 & 80.948 \\
Session 3 & $5: 06$ & 5890003.122 & 6508633.952 & 80.943 \\
Session 4 & $6: 13$ & 5890003.130 & 6508633.927 & 80.952 \\
Session 5 & $7: 02$ & 5890003.120 & 6508633.940 & 80.946 \\
\hline \multicolumn{5}{|c|}{ Point 3 } \\
\hline Session 1 & $1: 09$ & 5889998.357 & 6508641.253 & 80.528 \\
Session 2 & $2: 03$ & 5889998.353 & 6508641.240 & 80.531 \\
Session 3 & $5: 06$ & 5889998.350 & 6508641.229 & 80.526 \\
Session 4 & $6: 13$ & 5889998.353 & 6508641.242 & 80.546 \\
Session 5 & $7: 02$ & 5889998.348 & 6508641.240 & 80.537 \\
\hline
\end{tabular}

Tab. 6. Reference values of reduced distance in a horizontal plane and the difference of height between points of test network measured by a laser station

\begin{tabular}{|c|c|c|c|c|c|}
\hline \multicolumn{3}{|c|}{ D horizontal distance [m] } & \multicolumn{3}{c|}{ dH relative height [m] } \\
\hline $\mathbf{1 - 2}$ & $\mathbf{2 - 3}$ & $\mathbf{3 - 1}$ & $\mathbf{1 - 2}$ & $\mathbf{2 - 3}$ & $\mathbf{3 - 1}$ \\
\hline 10.113 & 8.727 & 11.234 & 0.537 & -0.408 & -0.129 \\
\hline
\end{tabular}

\section{Results of post-processing observation sessions}

In the Figure 3 below, absolute values of deviations of the resultant of horizontal coordinates of position on the points of geodesy test network for all measurement sessions with use of particular services of precise positioning are presented. Results of each measurement session are marked by a different color. Largest deviations between reference and calculated coordinates determined for Point 2 are respectively: $0.115 \mathrm{~m}$ for northern component $\mathrm{N}, 0.054 \mathrm{~m}$ for eastern component $\mathrm{E}$, and $0.115 \mathrm{~m}$ for vertical component $\mathrm{H}$. Comparing graphs presented in Figure 3 , one may notice a higher accuracy of the resultant of horizontal coordinates of position on the Point 3 where largest values of deviation of coordinates are respectively: $0.098 \mathrm{~m}$ for northern component $\mathrm{N}, 0.026 \mathrm{~mm}$ for eastern component $\mathrm{E}$ and 0.045 for vertical component $\mathrm{H}$. In the case of deviations of vertical component $\mathrm{H}$ the largest value is $0.115 \mathrm{~m}$ (Fig 4, Tab. 9) for Point 2. Most accurate determination of components of horizontal coordinates of position were achieved by employing GMV IGS Rapid service (Tab. 7, 8). GMV IGS Final service proved to be less accurate. In the case of the vertical component of the position the best results were achieved by GMV IGS 
Final service in contrast to CSRS service (Tab. 9). The above mentioned services achieved best accuracy with use IGS Final products. Largest errors when determining components of horizontal coordinates (Figure 3) and heights (Figure 4) appeared for GAPS service which used IGS Rapid products.

Tab. 7. Statistics of northern component $(\mathrm{N})$ of coordinates of position on points of test network for all observation sessions

\begin{tabular}{|c|c|c|c|c|c|c|c|c|c|c|}
\hline \multirow[t]{2}{*}{$\begin{array}{l}\text { Name of } \\
\text { service }\end{array}$} & \multirow[t]{2}{*}{$\begin{array}{l}\text { Name of } \\
\text { product }\end{array}$} & \multicolumn{3}{|c|}{$\begin{array}{c}\text { Mean } \\
\text { deviations } \\
{[N][\mathrm{cm}]}\end{array}$} & \multicolumn{3}{|c|}{$\begin{array}{c}\text { Standard } \\
\text { deviations } \\
\text { STD N [cm] }\end{array}$} & \multicolumn{3}{|c|}{$\begin{array}{c}\text { Maximum } \\
\text { deviations } \\
|N|[\mathrm{cm}]\end{array}$} \\
\hline & & 1 & 2 & 3 & 1 & 2 & 3 & 1 & 2 & 3 \\
\hline GMV & GMV Rapid & 0.9 & 1.5 & 0.9 & 0.8 & 1.9 & 0.3 & 2.2 & 4.7 & 1.1 \\
\hline GMV & IGS Rapid & 0.9 & 1.2 & 1.5 & 0.5 & 0.6 & 0.6 & 1.3 & 1.7 & 2.4 \\
\hline GMV & IGS Final & 1.5 & 1.7 & 1.1 & 1.8 & 1.8 & 0.7 & 4.7 & 4.7 & 1.9 \\
\hline CSRS & IGS Final & 1.0 & 1.5 & 1.7 & 0.9 & 1.1 & 1.7 & 2.3 & 2.7 & 4.6 \\
\hline APPS & JPL Final & 1.4 & 1.9 & 0.6 & 1.5 & 1.8 & 0.7 & 4.1 & 4.7 & 1.8 \\
\hline GAPS & IGS Rapid & 2.7 & 3.3 & 3.1 & 3.5 & 4.6 & 3.9 & 9.0 & 11.5 & 9.8 \\
\hline GAPS & IGS Final & 1.9 & 1.7 & 1.5 & 2.4 & 2.1 & 1.7 & 6.1 & 5.4 & 4.5 \\
\hline
\end{tabular}

Tab. 8. Statistics of eastern component $(E)$ of coordinates of position on points of test network for all observation sessions

\begin{tabular}{|c|c|c|c|c|c|c|c|c|c|c|}
\hline \multirow[t]{2}{*}{$\begin{array}{c}\text { Name of } \\
\text { service }\end{array}$} & \multirow[t]{2}{*}{$\begin{array}{l}\text { Name of } \\
\text { product }\end{array}$} & \multicolumn{3}{|c|}{$\begin{array}{c}\text { Mean } \\
\text { deviations } \\
|E|[\mathrm{cm}]\end{array}$} & \multicolumn{3}{|c|}{$\begin{array}{c}\text { Standard } \\
\text { deviations } \\
\text { STD E [cm] }\end{array}$} & \multicolumn{3}{|c|}{$\begin{array}{c}\text { Maximum } \\
\text { deviations } \\
|E|[\mathrm{cm}]\end{array}$} \\
\hline & & 1 & 2 & 3 & 1 & 2 & 3 & 1 & 2 & 3 \\
\hline GMV & GMV Rapid & 1.6 & 2.1 & 1.6 & 0.9 & 1.9 & 0.4 & 3.2 & 5.4 & 2.2 \\
\hline GMV & IGS Rapid & 1.5 & 1.5 & 1.8 & 0.4 & 0.5 & 0.7 & 2.1 & 2.2 & 2.6 \\
\hline GMV & IGS Final & 1.7 & 2.0 & 1.7 & 0.8 & 1.3 & 0.3 & 3.1 & 4.3 & 2.1 \\
\hline CSRS & IGS Final & 1.6 & 1.9 & 1.7 & 0.9 & 1.4 & 0.4 & 3.2 & 4.4 & 2.3 \\
\hline APPS & JPL Final & 1.6 & 1.9 & 1.3 & 1.1 & 1.5 & 0.2 & 3.2 & 4.5 & 1.6 \\
\hline GAPS & IGS Rapid & 1.7 & 1.6 & 2.0 & 0.6 & 0.8 & 0.5 & 2.6 & 2.5 & 2.6 \\
\hline GAPS & IGS Final & 2.4 & 2.5 & 1.9 & 1.1 & 1.2 & 0.5 & 4.4 & 4.8 & 2.5 \\
\hline
\end{tabular}

On the basis of results of measurements presented in Figures 3 and 4 and Tables 7, 8, 9 it can be drawn that at least two-hour long measurement sessions achieves an absolute position with an accuracy of 2-4 cm. The use of IGS Final products which are characterized by their high accuracy requires waiting period of more than couple days (11-18 days) for their availability. Therefore, calculations for GMV and GAPS services using Rapid products which are made available after more than couple hours were conducted. When employing PPP services with use of Rapid products for at least 2 hours sessions, maximum deviations of coordinates were respectively: $0.026 \mathrm{~m}$ for northern component, $0.024 \mathrm{~m}$ for eastern component, $0.035 \mathrm{~m}$ for resultant NE (Tab. 10) and $0.039 \mathrm{~m}$ for vertical component (Tab. 11). 
a)
[m]
NE - point 1

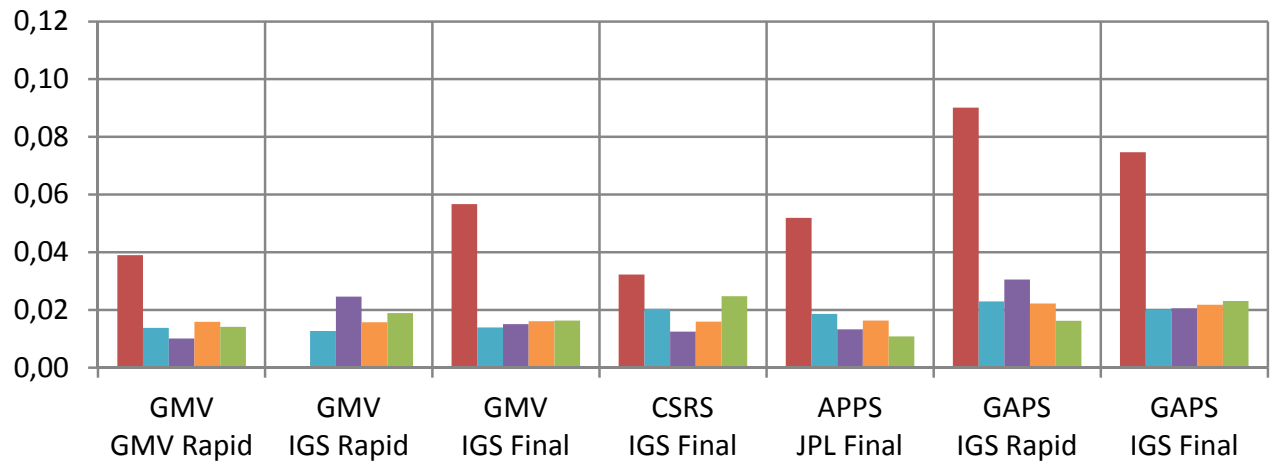

- Session 1 1:09

Session 2 2:03

Session 3 5:06

Session 4 $6: 13$

- Session 5 7:02

b)
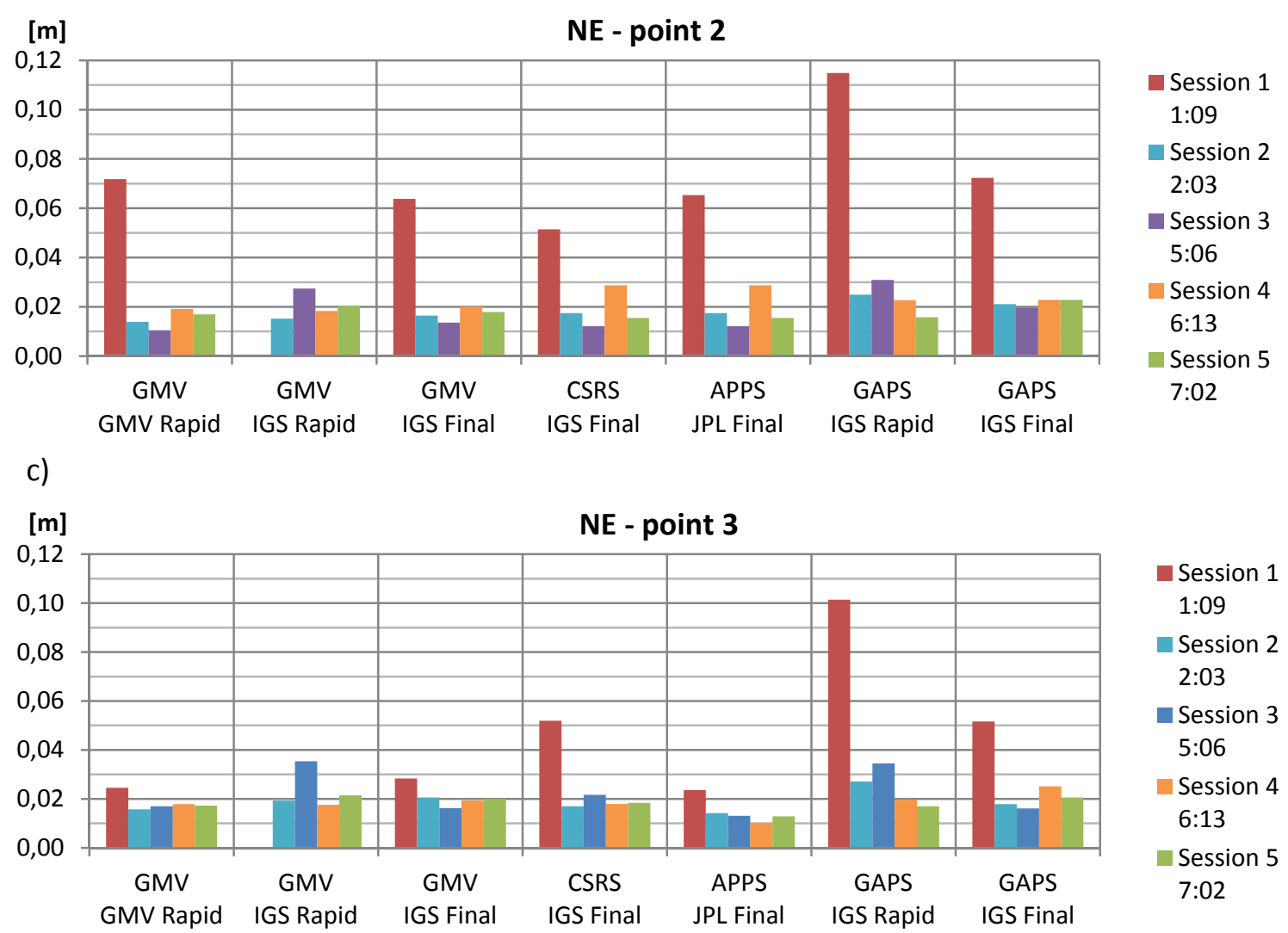

Fig. 3. Deviation of the resultant NE (North-East) of horizontal coordinates of position on: a) point 1, b) point 2, c) point 3

By comparing acquired results to analogic post-processing with the use of Final products for the same service provider, it was noted that achieved accuracies are comparable. Similar conclusions stem from results presented in Tables 10 and 11 where statistics of the horizontal resultant and vertical component of position on points of test network for at least 2 hours observation sessions are presented. Thus, it can be assumed that when conducting calculations after finalizing measurements before disclosing Final products, the use of Rapid products allows for comparable accuracy of positioning. By analyzing results in Figure 4 and Table 9, it may be noted that for all observation sessions the range of accuracy of maximum deviation of the vertical component of position is between $0.006 \mathrm{~m}$ to 0.115 on the point 2 where the lowest values of deviations of the vertical component were achieved by employing GMV service with the use of GMV Rapid and IGS Final products. 
a)

[m]

0,12

0,10

0,08

0,06

0,04

0,02

0,00

b)

[m]

0,12

0,10

0,08

0,06

0,04

0,02

0,00

c)

[m]

$\begin{aligned} & 0,12 \\ & 0,10 \\ & 0,08 \\ & 0,06 \\ & 0,04 \\ & 0,02 \\ & 0,00\end{aligned}-$

GMV

GMV Rapid IGS Rapid

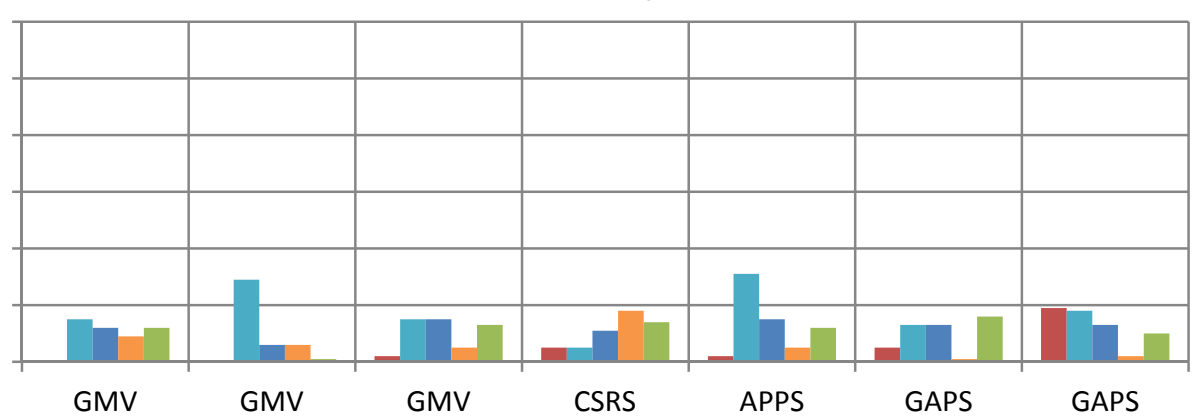

GMV Rapid IGS Rapid IGS Final IGS Final JPL Final IGS Rapid IGS Final

Session 1

1:09

- Session 2

2:03

- Session 3

5:06

Session 4

6:13

Session 5

7:02

\section{H - point 2}

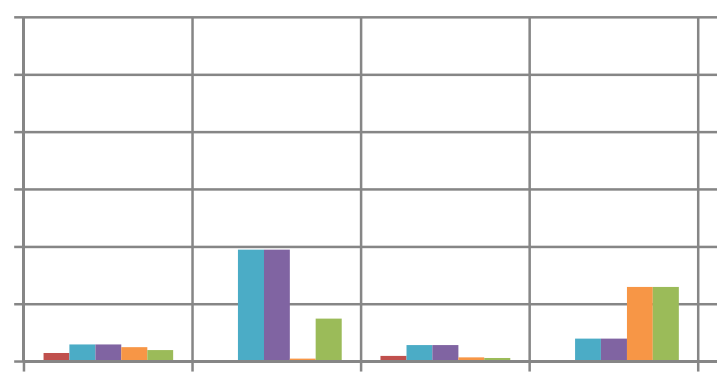

GMV

GMV

GMV

CSRS

IGS Final

IGS Final

H - point 3

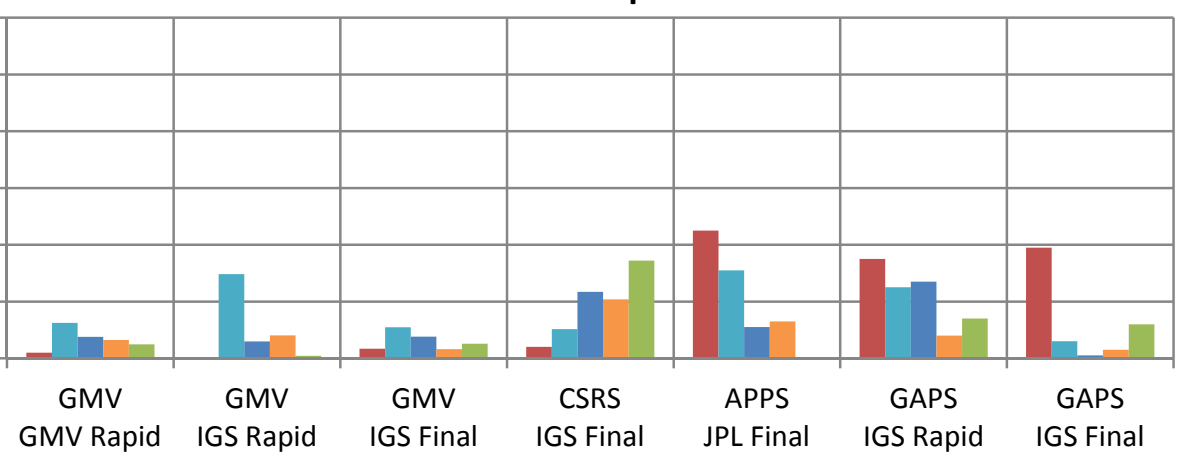

Fig. 4. Deviations of the height coordinate $\mathrm{H}$ of positions on:

a) point 1, b) point $2, \mathrm{c})$ point 3

Tab. 9. Statistics of the height coordinate $\mathrm{H}$ of positions on points of test network for all observation sessions

\begin{tabular}{|c|c|c|c|c|c|c|c|c|c|c|}
\hline \multirow[t]{2}{*}{$\begin{array}{l}\text { Name of } \\
\text { service }\end{array}$} & \multirow[t]{2}{*}{$\begin{array}{l}\text { Name of } \\
\text { product }\end{array}$} & \multicolumn{3}{|c|}{$\begin{array}{c}\text { Mean } \\
\text { deviations } \\
|\mathrm{H}|[\mathrm{cm}]\end{array}$} & \multicolumn{3}{|c|}{$\begin{array}{c}\text { Standard } \\
\text { deviation } \\
\text { STD H }[\mathrm{cm}]\end{array}$} & \multicolumn{3}{|c|}{$\begin{array}{c}\text { Maximum } \\
\text { deviations } \\
|\mathrm{H}|[\mathrm{cm}]\end{array}$} \\
\hline & & 1 & 2 & 3 & 1 & 2 & 3 & 1 & 2 & 3 \\
\hline GMV & GMV Rapid & 1.0 & 0.5 & 0.7 & 0.6 & 0.1 & 0.4 & 1.5 & 0.6 & 1.2 \\
\hline GMV & IGS Rapid & 1.1 & 2.3 & 1.1 & 1.3 & 1.9 & 1.3 & 2.9 & 3.9 & 3.0 \\
\hline GMV & IGS Final & 1.0 & 0.3 & 0.6 & 0.6 & 0.2 & 0.3 & 1.5 & 0.6 & 1.1 \\
\hline CSRS & IGS Final & 1.1 & 1.4 & 1.9 & 0.6 & 1.2 & 1.2 & 1.8 & 2.6 & 3.4 \\
\hline APPS & JPL Final & 1.3 & 1.7 & 2.0 & 1.1 & 1.1 & 1.8 & 3.1 & 2.5 & 4.5 \\
\hline GAPS & IGS Rapid & 1.0 & 3.8 & 2.2 & 0.6 & 4.4 & 1.1 & 1.6 & 11.5 & 3.5 \\
\hline GAPS & IGS Final & 1.2 & 3.2 & 1.2 & 0.7 & 2.3 & 1.6 & 1.9 & 7.2 & 3.9 \\
\hline
\end{tabular}


Second experiment results on Figures 5 and 6 below, present deviation of absolute values of horizontal distance and the relative height between points of test network of all measurement sessions with use of each PPP service respectively. Similarly, each measurement session is marked with a different color. By comparing graphs on figure 5, a higher accuracy of determining horizontal distance of a triangle side 1-2 may be noticed. The maximum difference of reference values (Tab. 6) in relation to those calculated for triangle side 1-2 is: $0.019 \mathrm{~m}$ for the horizontal distance, $0.034 \mathrm{~m}$ for the relative height. Mean deviations between points 1 and 2 are: for the horizontal distance $\mathrm{D}=0.008 \mathrm{~m}$, for the relative height $\mathrm{dH}=0.013 \mathrm{~m}$. By analyzing the figure 6 the smallest values of deviations can be noticed in the case of distance of a triangle side 2-3 where maximum values are: 0.018 for the relative height and $0.053 \mathrm{~m}$ for the horizontal distance. From data gathered during observation sessions, the smallest values of maximum deviations for determination of the horizontal distance and the relative height were achieved through the use of GMV service (Tab. 12,13). Negligibly, larger errors were achieved through the use of GAPS IGS Final service. In determining the relative height the highest accuracy was achieved through GMV IGS Final service and then through GAPS IGS Final service (Tab. 13). All featured services achieved the best results through the use of Final products. The largest errors occurred for determination of the horizontal distance (Figure 5) and the relative height (Figure 6) when APPS service was employed which used JPL Final products.

Tab. 10. Statistics of the resultant NE (North-East) of horizontal coordinates of positions on points of test network for at least 2 hours observation sessions

\begin{tabular}{|c|c|c|c|c|c|c|c|c|c|c|}
\hline \multirow{2}{*}{$\begin{array}{c}\text { Name of } \\
\text { service }\end{array}$} & \multirow{2}{*}{$\begin{array}{c}\text { Name of } \\
\text { product }\end{array}$} & \multicolumn{3}{|c|}{$\begin{array}{c}\text { Mean deviations } \\
\text { [NEI [cm] }\end{array}$} & \multicolumn{3}{c|}{$\begin{array}{c}\text { Standard deviation } \\
\text { STD NE [cm] }\end{array}$} & \multicolumn{3}{|c|}{$\begin{array}{c}\text { Maximum deviations } \\
\text { [NE| [cm] }\end{array}$} \\
\cline { 3 - 12 } & & $\mathbf{1}$ & $\mathbf{2}$ & $\mathbf{3}$ & $\mathbf{1}$ & $\mathbf{2}$ & $\mathbf{3}$ & $\mathbf{1}$ & $\mathbf{2}$ & $\mathbf{3}$ \\
\hline GMV & GMV Rapid & 1.4 & 1.5 & 1.7 & 0.2 & 0.4 & 0.1 & 1.6 & 1.9 & 1.8 \\
\hline GMV & IGS Rapid & 1.8 & 2.0 & 2.3 & 0.5 & 0.5 & 0.8 & 2.5 & 2.7 & 3.5 \\
\hline GMV & IGS Final & 1.5 & 1.7 & 1.9 & 0.1 & 0.3 & 0.2 & 1.6 & 2.0 & 2.1 \\
\hline CSRS & IGS Final & 1.8 & 1.8 & 1.9 & 0.5 & 0.7 & 0.2 & 2.5 & 2.9 & 2.2 \\
\hline APPS & JPL Final & 1.5 & 1.8 & 1.3 & 0.3 & 0.7 & 0.2 & 1.9 & 2.9 & 1.4 \\
\hline GAPS & IGS Rapid & 2.3 & 2.4 & 2.5 & 0.6 & 0.6 & 0.8 & 3.1 & 3.1 & 3.4 \\
\hline GAPS & IGS Final & 2.1 & 2.2 & 2.0 & 0.1 & 0.2 & 0.4 & 2.3 & 2.3 & 2.5 \\
\hline
\end{tabular}

Tab. 11. Statistics of the coordinate $\mathrm{H}$ of positions on points of test network for at least 2 hours observation sessions

\begin{tabular}{|c|c|c|c|c|c|c|c|c|c|c|}
\hline \multirow{2}{*}{$\begin{array}{l}\text { Name of } \\
\text { service }\end{array}$} & \multirow{2}{*}{$\begin{array}{l}\text { Name of } \\
\text { product }\end{array}$} & \multicolumn{3}{|c|}{$\begin{array}{c}\text { Mean Deviations } \\
|\mathrm{H}|[\mathrm{cm}]\end{array}$} & \multicolumn{3}{|c|}{$\begin{array}{c}\text { Standard Deviations } \\
\text { STD H }[\mathrm{cm}]\end{array}$} & \multicolumn{3}{|c|}{$\begin{array}{c}\text { Maximum Deviations } \\
{[\mathrm{H} \mid[\mathrm{cm}]}\end{array}$} \\
\hline & & 1 & 2 & 3 & 1 & 2 & 3 & 1 & 2 & 3 \\
\hline GMV & GMV Rapid & 1.2 & 0.5 & 0.8 & 0.2 & 0.1 & 0.3 & 1.5 & 0.6 & 1.2 \\
\hline GMV & IGS Rapid & 1.1 & 2.3 & 1.1 & 1.3 & 1.9 & 1.3 & 2.9 & 3.9 & 3.0 \\
\hline GMV & IGS Final & 1.2 & 0.4 & 0.7 & 0.5 & 0.3 & 0.3 & 1.5 & 0.6 & 1.1 \\
\hline CSRS & IGS Final & 1.2 & 1.7 & 2.2 & 0.5 & 1.0 & 1.0 & 1.8 & 2.6 & 3.4 \\
\hline APPS & JPL Final & 1.6 & 1.5 & 1.4 & 1.1 & 1.2 & 1.3 & 3.1 & 2.5 & 3.1 \\
\hline GAPS & IGS Rapid & 1.1 & 1.9 & 1.9 & 0.7 & 1.0 & 0.9 & 1.6 & 3.0 & 2.7 \\
\hline GAPS & IGS Final & 1.1 & 2.2 & 0.5 & 0.7 & 0.2 & 0.5 & 1.8 & 2.3 & 1.2 \\
\hline
\end{tabular}


On the basis of results presented in Figures 5 and 6 and Tables 12 and 13, it may be concluded that at least two-hour measurement sessions allow for determination of the horizontal distance or the relative height with an accuracy of 1-2 cm. Similarly, in determining the location of single points of the network calculations were done for the horizontal distance and the relative height employing GMV and GAPS services considering Rapid products which are made available after 10 hours. When Rapid products are used for at least 2 hours sessions the maximum deviations are accordingly: $0.020 \mathrm{~m}$ for the horizontal distance and $0.021 \mathrm{~m}$ for the relative height (Tab. 12, 13). When analyzing acquired results for the same service provider using Final products, it was noticed that the use of Rapid products allows for close accuracy in positioning.

a)

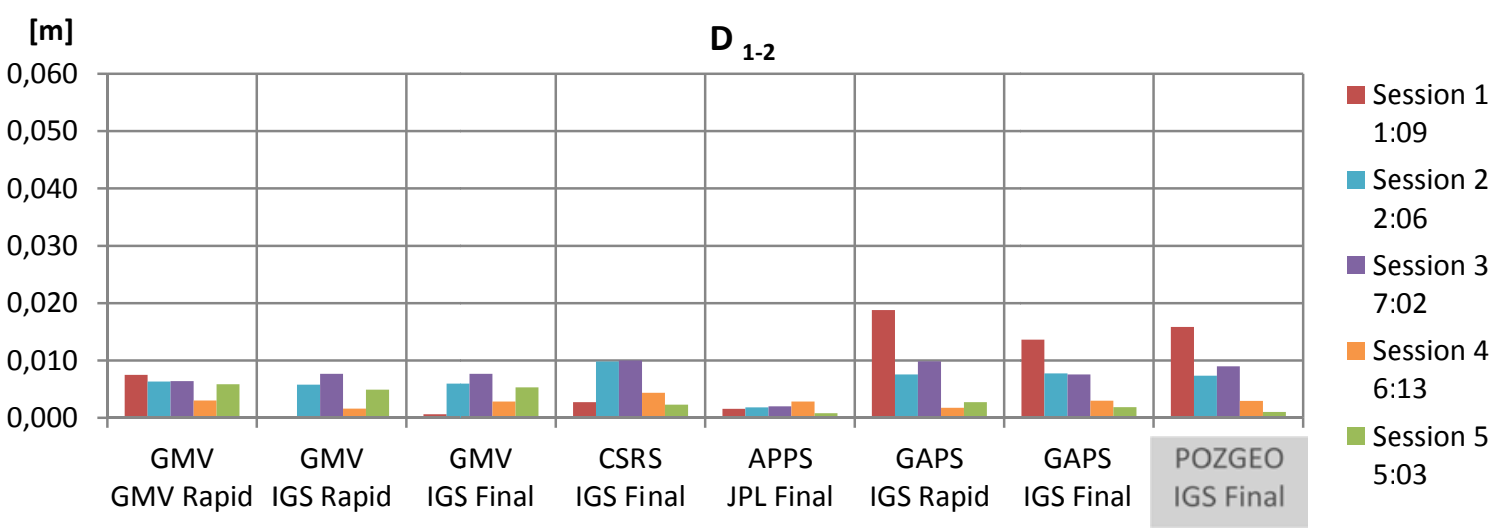

b)

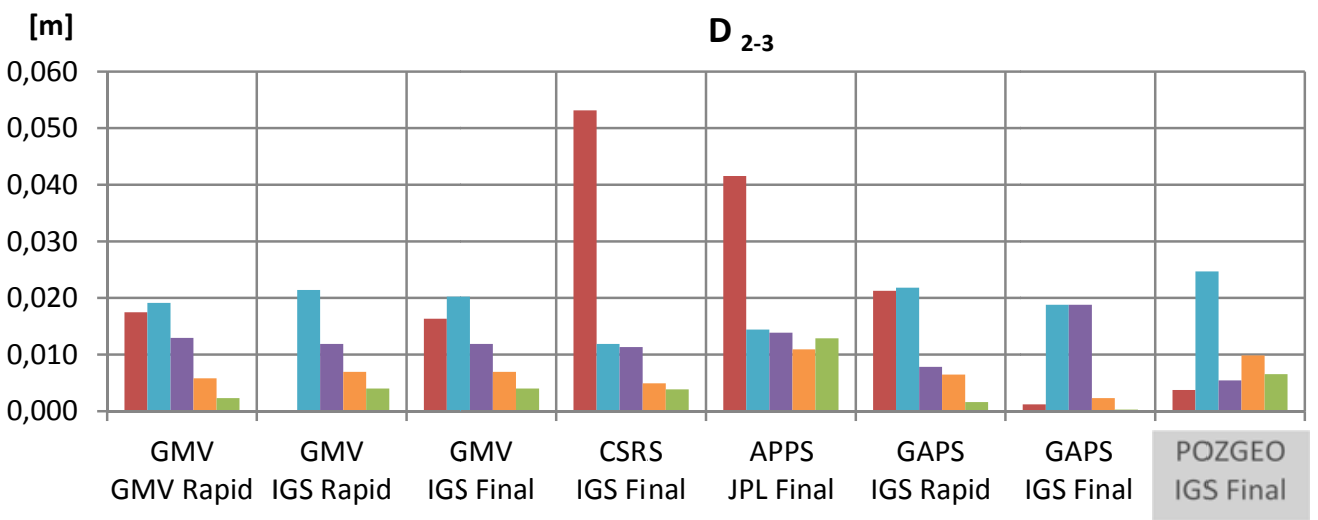

Session 1 1:09

Session 2 2:06

- Session 3 7:02

Session 4 6:13

Session 5 5:03

c)

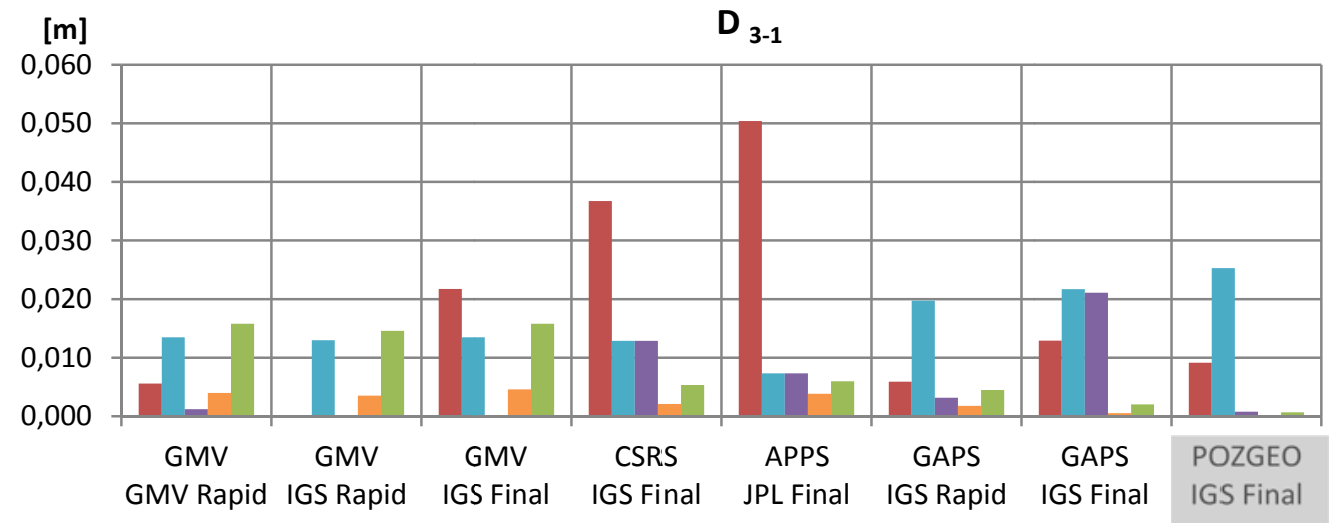

Fig. 5. Deviation of the horizontal distance $D$ between points of test network for all observation sessions 
Tab. 12. Statistics for the horizontal distance $D$ between points of test network for at least 2 hours observation sessions

\begin{tabular}{|c|c|c|c|c|c|c|c|c|c|c|}
\hline \multirow{2}{*}{$\begin{array}{c}\text { Name of } \\
\text { service }\end{array}$} & \multirow{2}{*}{$\begin{array}{c}\text { Name of } \\
\text { product }\end{array}$} & \multicolumn{3}{|c|}{$\begin{array}{c}\text { Mean deviations } \\
\text { |D| [cm] }\end{array}$} & \multicolumn{3}{c|}{$\begin{array}{c}\text { Standard deviation } \\
\text { STD D [cm] }\end{array}$} & \multicolumn{3}{c|}{$\begin{array}{c}\text { Maximum deviations } \\
\text { [D| [cm] }\end{array}$} \\
\cline { 3 - 12 } & & $\mathbf{1 - 2}$ & $\mathbf{2 - 3}$ & $\mathbf{3 - 1}$ & $\mathbf{1 - 2}$ & $\mathbf{2 - 3}$ & $\mathbf{3 - 1}$ & $\mathbf{1 - 2}$ & $\mathbf{2 - 3}$ & $\mathbf{3 - 1}$ \\
\hline GMV & GMV Rapid & 0.5 & 1.0 & 0.9 & 0.2 & 0.2 & 0.7 & 0.6 & 0.6 & 1.6 \\
\hline GMV & IGS Rapid & 0.5 & 1.1 & 0.8 & 0.3 & 0.3 & 0.7 & 0.8 & 0.8 & 1.5 \\
\hline GMV & IGS Final & 0.5 & 1.1 & 0.8 & 0.2 & 0.2 & 0.7 & 0.8 & 0.8 & 1.6 \\
\hline CSRS & IGS Final & 0.7 & 0.8 & 0.8 & 0.4 & 0.4 & 0.5 & 1.0 & 1.0 & 1.3 \\
\hline APPS & JPL Final & 0.2 & 1.3 & 0.6 & 0.1 & 0.1 & 0.2 & 0.3 & 0.3 & 0.7 \\
\hline GAPS & IGS Rapid & 0.5 & 0.9 & 0.7 & 0.4 & 0.4 & 0.8 & 1.0 & 1.0 & 2.0 \\
\hline GAPS & IGS Final & 0.5 & 1.0 & 1.1 & 0.3 & 0.3 & 1.2 & 0.8 & 0.8 & 2.2 \\
\hline POZGEO & IGS Final & 0.5 & 1.2 & 0.7 & 0.4 & 0.4 & 1.2 & 0.9 & 0.9 & 2.5 \\
\hline
\end{tabular}

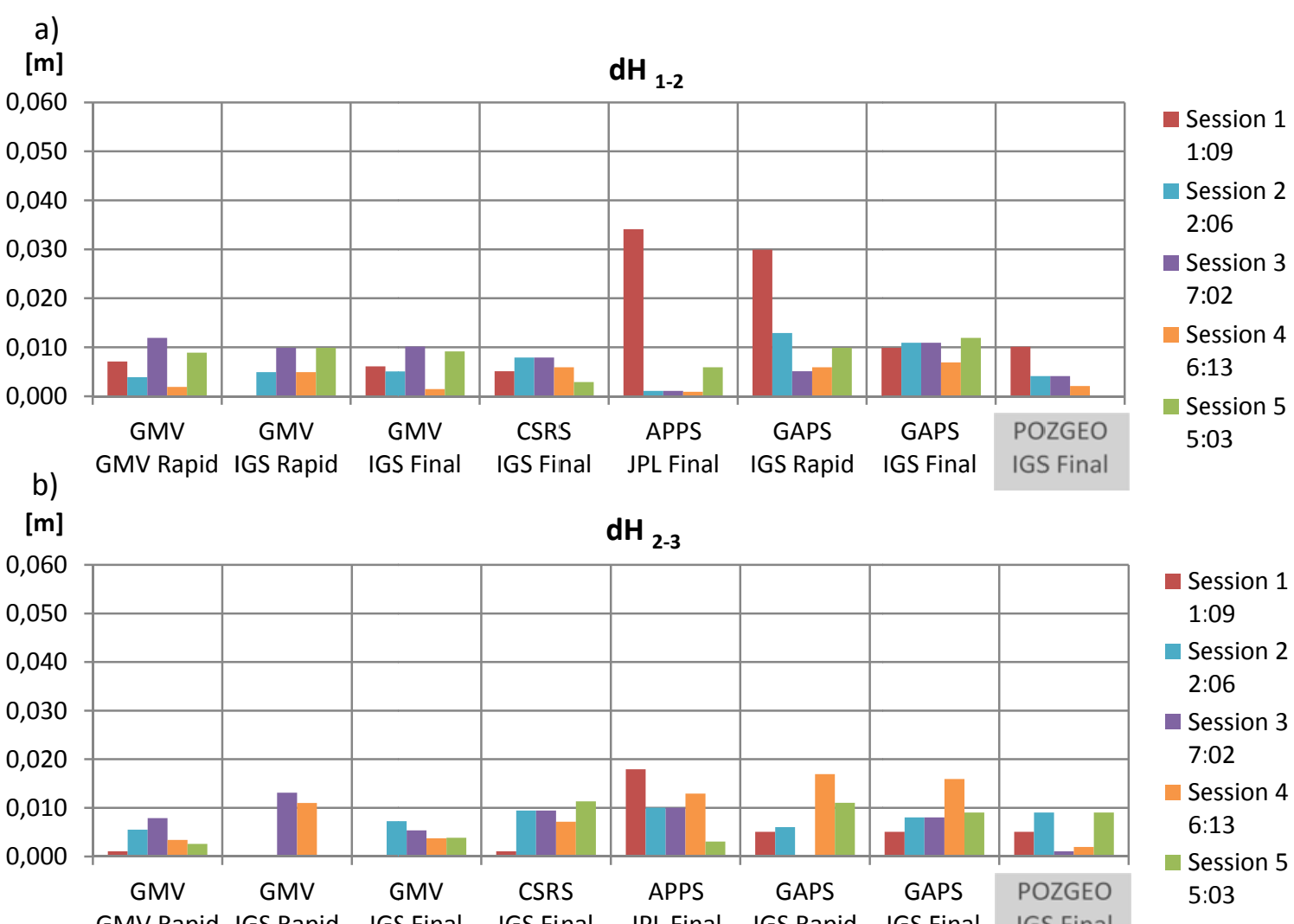

c) GMV Rapid IGS Rapid IGS Final IGS Final JPL Final IGS Rapid IGS Final IGS Final

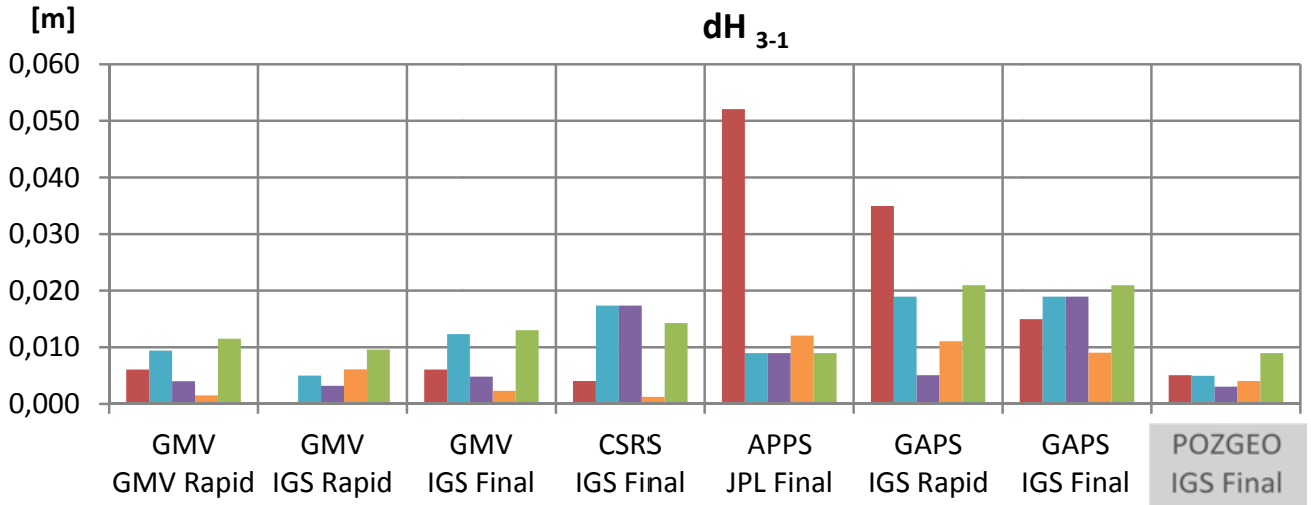

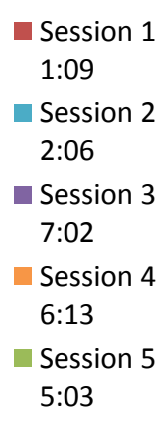

Fig. 6. Deviation of the relative height $\mathrm{dH}$ between points of test network for all observation sessions 
After the analysis of results presented in Figure 5, it was concluded that for all observation sessions the smallest deviations $D$ occur at the horizontal distance between points 1 and 2. Whereas, at distances 2-3 and 3-1, deviations of the horizontal distance $D$ are two times larger. This relationship may stem from the location of points of test network in relation to orientation of the axis of coordinate system. The direction of a triangle side 1-2 is close to the north direction whereas directions of the other two sides 2-3 and 3-1 are close to the east direction. The north component is most commonly characterized with a higher accuracy (Tab. 7) which is favorable for decreasing deviations for distances 1-2. By analyzing results on Figure 6 , it may be noticed that for at least 2 hours observation sessions the maximum deviation of the relative height is equal $0.021 \mathrm{~mm}$ for the side 3-1 of test network. Regardless of the orientation of the measured length the smallest values of maximum deviation of the relative height were achieved by GMV service with the use of GM Rapid, IGS Rapid and IGS Final products. The values of deviations achieved for calculations of the horizontal distance and the relative height for at least 2 hours observation sessions are comparable with deviations achieved by POZGEO service.

Tab. 13. Statistics for the relative height $\mathrm{dH}$ between points of test network for at least 2 hours observation sessions

\begin{tabular}{|c|c|c|c|c|c|c|c|c|c|c|}
\hline \multirow{2}{*}{$\begin{array}{c}\text { Name of } \\
\text { service }\end{array}$} & \multirow{2}{*}{$\begin{array}{c}\text { Name of } \\
\text { product }\end{array}$} & \multicolumn{3}{|c|}{$\begin{array}{c}\text { Mean deviations } \\
\text { |dH| [cm] }\end{array}$} & \multicolumn{2}{c|}{$\begin{array}{c}\text { Standard deviation } \\
\text { STD dH [cm] }\end{array}$} & \multicolumn{3}{|c|}{$\begin{array}{c}\text { Maximum deviations } \\
\text { [dH| [cm] }\end{array}$} \\
\cline { 3 - 12 } & & $\mathbf{1 - 2}$ & $\mathbf{2 - 3}$ & $\mathbf{3 - 1}$ & $\mathbf{1 - 2}$ & $\mathbf{2 - 3}$ & $\mathbf{3 - 1}$ & $\mathbf{1 - 2}$ & $\mathbf{2 - 3}$ & $\mathbf{3 - 1}$ \\
\hline GMV & GMV Rapid & 0.7 & 0.5 & 0.7 & 0.5 & 0.2 & 0.5 & 1.2 & 0.8 & 1.1 \\
\hline GMV & IGS Rapid & 0.7 & 0.6 & 0.6 & 0.3 & 0.7 & 0.3 & 1.0 & 1.3 & 1.0 \\
\hline GMV & IGS Final & 0.6 & 0.5 & 0.8 & 0.4 & 0.2 & 0.5 & 1.0 & 0.7 & 1.3 \\
\hline CSRS & IGS Final & 0.6 & 0.9 & 1.3 & 0.2 & 0.2 & 0.8 & 0.8 & 1.1 & 1.7 \\
\hline PPS & JPL Final & 0.2 & 0.9 & 1.0 & 0.2 & 0.4 & 0.2 & 0.6 & 1.3 & 1.2 \\
\hline GAPS & IGS Rapid & 0.8 & 0.9 & 1.4 & 0.4 & 0.7 & 0.7 & 1.3 & 1.7 & 2.1 \\
\hline GAPS & IGS Final & 1.0 & 1.0 & 1.7 & 0.2 & 0.4 & 0.5 & 1.2 & 1.6 & 2.1 \\
\hline POZGEO & IGS Final & 0.3 & 0.5 & 0.5 & 0.2 & 0.4 & 0.3 & 0.4 & 0.9 & 0.9 \\
\hline
\end{tabular}

\section{Summary and conclusions}

The data presented above show the analysis of the accuracy of PPP method depending on the length of observation session and the use of permanent service which conducts calculations through PPP technique. Results of research coordinates established horizontal distances and relative height for a triangular test network. Analyses were done with use of four permanent services such as: APPS, CSRSPPP, GAPS and magicGNSS. During analysis of deviations for the horizontal distance (D) and the relative height $(\mathrm{dH})$, results of measurements made by a laser station Leica TDRA6000 were adopted as reference values. When determining deviations of the horizontal resultant (NE) and the vertical component $(\mathrm{H})$ on points of the test network, calculations conducted with the use of POZGEO service were used as reference values where mean errors of position and determination of the height were accordingly: $m_{p}=0.006 \mathrm{~m} ; \mathrm{m}_{\mathrm{h}}=0.003 \mathrm{~m}$ for the longest session and: $\mathrm{m}_{\mathrm{p}}=$ $0.009 \mathrm{~m} ; \mathrm{m}_{\mathrm{h}}=0.006 \mathrm{~m}$ for the shortest session. In order to achieve a higher accuracy of reference values than sub-centimeter for POZGEO service daily observation sessions should have been conducted to yield millimeter accuracy. 
On the basis of acquired results (Tab. 10,11) of determining the position of single points of the test network, it can be concluded that at least two-hour long measurements achieves positioning with an accuracy of $2-4 \mathrm{~cm}$. The analysis of results presented in Figures 5 and 6 reveal that one-hour long measurement sessions determines the horizontal distance or the relative height for sides of the triangle test network with direction close to north direction with accuracy of $1-3 \mathrm{~cm}$ and for sides with direction close to east direction with accuracy of 2-6 cm. The analyses of results in Table 12 and 13 shows that at least two-hours long measurement sessions can be used to determine the horizontal distance or the difference in height with an accuracy of 1-2 cm. In order to achieve higher accuracies a longer observation session should have been conducted.

Post-processing of measurements with the use of Rapid products show that achieving high accuracy of PPP is possible without waiting for disclosure of Final products. Rapid products employed in PPP calculations achieve accuracy in determining coordinates on a close level as post-processing employs Final products.

The presented scope of research can be extended by increasing the number of observation sessions or by dividing them into shorter intervals. Additionally, incorporating more satellite constellations such as: GLONASS, Galileo, BeiDou may also have impact on the shortening of the measurement session and achieving the same accuracy as for a single GPS constellation.

\section{References}

Cai Ch., Gao Y., (2007). Precise point positioning using combined GPS and GLONASS observations, Journal of Global Positioning Systems, vol 6, no 1, pp. 13-22.

Choy S., (2011). High accuracy precise point positioning using a single frequency GPS receiver, Journal of Applied Geodesy, vol 5, pp. 59-69.

Gao Y., Chen K., (2004). Performance analysis of precise point positioning using reatime orbit and clock products, Journal of Global Positioning Systems, vol 3, no 1-2, pp. 95-100.

Gao Y. (2011) Precise point positioning and its challenges, aided GNSS and signal tracking, Inside GNSS, vol 1 no 8, pp,16-18.

Geng J., Meng X., Dodson A.H., Teferle F.N. (2010) Integer ambiguity resolution in precise point positioning: method comparison, Journal of Geodesy, vol 84 no 9, pp. 569-581.

Guo Q., (2015). Precision comparison and analysis of four online free PPP services in static positioning and tropospheric delay estimation, GPS Solutions vol. 19 no 4, pp. 537-544.

Kouba J., Héroux P., (2001). Precise point positioning using IGS orbit and clock products, GPS Solutions, vol 5 no 2, pp. 12-28.

Leandro R.F., Santos M.C., Langley R.B., (2009). Analyzing GNSS data in precise point positioning software, GPS Solutions, vol 15, no1, pp. 1-13.

Rizos C., Janssen V., Roberts C., Grinter T. (2012). Precise point positioning: is the era of differential GNSS positioning drawing to an end?, FIG Working Week 2012, Rome, Italy.

Rogowski J. B., Figurski M. (2004). Ziemskie systemy i układy odniesienia oraz ich realizacje. W: Nowe obowiązujące niebieskie $i$ ziemskie systemy $i$ układy odniesienia oraz ich wzajemne relacje. Warszawa, IGiK, s. 37-68. 
Stępniak K., Wielgosz P., Paziewski J. (2012). Badania dokładności pozycjonowania techniką PPP w zależności od odległości sesji obserwacyjnej oraz wykorzystanych systemów pozycjonowania satelitarnego, Biuletyn WAT, nr 1/2012, s. 429-450.

Zumberge J.F., Heflin M.B., Jefferson D.C., Watkins M.M., Webb F.H. (1997) Precise point positioning for the efficient and robust analysis of GPS data from large networks, Journal of Geophysical Research, vol. 102(B3), pp. 5005-5017.

\section{Authors:}

Marcin Malinowski ${ }^{1}$, marcinm@utp.edu.pl

Janusz Kwiecień ${ }^{1)}$, jkw@utp.edu.pl

1) UTP University of Science and Technology in Bydgoszcz,

Faculty of Civil and Environmental Engineering and Architecture, Poland 